\title{
Fluorine F 18-labeled 2-FACPC
}

National Cancer Institute

\section{Source}

National Cancer Institute. Fluorine F18-labeled 2-FACPC. NCI Thesaurus. Code C120070.

A radioconjug ate composed of an analog of the synthetic, alicyclic amino acid aminocyclopentane carboxylic acid (ACPC) radiolabeled with the positron-emitting isotope fluorine $\mathrm{F} 18$ (2-[18F]FACPC), with potential cancer cell imaging activity during positron emission tomography (PET). As tumor cells have a higher rate of protein synthesis than normal, healthy cells, upon administration, fluorine $\mathrm{F} 18$ labeled 2-FACPC is selectively taken up by rapidly proliferating tumor cells through the sodium-independent subtype $L$ amino acid transport system (AAT) which leads to the accumulation of this tracer in tumor cells. Upon PET, tumor cells can then be visualized. 